\title{
Improvement of Characteristics Geotechnics of the Clay Soils by Incorporation of Lime Case of Ouled Fayet and Cheraga
}

\author{
F.Z. Aissiou ${ }^{1, *}$, A. Nechnech ${ }^{1}$, H. Aissiou ${ }^{2}$ \\ ${ }^{1}$ Faculty of civil en gineering, Leego laboratory in Houari Boumediene University, Algiers, Algeria \\ ${ }^{2}$ Department of mechanical en gineering, Saad Dahlab University, Blida, Algeria \\ *Corresponding author: fa_aissiou2007@yahoo.fr
}

Received December 28, 2012; Revised May 27, 2013; Accepted May 28, 2013

\begin{abstract}
Lime is flexible hydraulics which has the property to improve the soil mechanics characteristics. For the muddy and argillaceous grounds, the traditional interaction between lime and their minerals is noticed immediately. The ground becomes friable and is drained, especially with the quicklime; the mixtu re can be stored for one short period (a few weeks) without its intrinsic properties not changing. For a good soil stabilization with lime it is necessary to lay out of certain relative data to the soil mechanics properties, like plasticity, granulometry and the water content to evaluate the possibilities for improvement. This work consists at the presentation of the results of a laboratory study on the treatment of a clay soil in the area of the Inhabitant of Algiers by incorporation of various contents extinct lime. For that, physical and mechanical tests such as (unconfined compression test, classification tests of the grounds in 1st place and shear test) were carried out and the results obtained highlight an unquestionable and definitely better improvement of the characteristics geotechnics such as the resistance of compression, resistance of shearing (angle of friction and cohesion).
\end{abstract}

Keywords: lime, clay soil, treatment, compression, shearing, characteristic geotechnics

\section{Introduction}

Recent research tasks carried out in Algeria and Europe [1] showed the aptitude of lime to improve the properties geotechnics of the ground by accelerating its structural modification. The incorporation of lime to a ground the short-term behavior during its use by its reaction results in to improve; with surplus water that it absorbs and by the capacity flocculating on clays. The long-term behavior, by developing the pozzolanic reaction of catch with the ores present. For a good soil stabilization with lime it is necessary to obtain homogeneous a ground mixture/lime is essential for the final quality of the embankment and coating [2].

\section{The Experimental Program}

\subsection{Choice of Materials Used}

The first ground used in this study was obtained to leave d' a site (construction project) pertaining to the building site of "Falcon Motors Algeria" of Chéraga located roughly at 18 kilometers of western south of Algiers, the area profits from a local climate of Mediterranean type semi - wet. Precipitations annual averages are between $700 \mathrm{~mm}$ and $800 \mathrm{~mm}$, strongest extend from October in February and almost non-existent in July and August. The second ground was obtained to leave d' a site located at Ouled Fayet. These two sites belong to the same area, the latter is known by these marnes plais ancians covering a broad surface in the southwest of the Sahel of A lgiers. These clays were extracted at the beginning of June 2007 with a depth from approximately $4.70 \sim 5.40 \mathrm{~m}$, a series of tests was carried out to classify each type of ground on the level of central laboratory of work public. The physical properties of the two grounds are presented in (Table 1).

Table 1. Physics soil characte ristics stu died

\begin{tabular}{|c|c|c|}
\hline Basic characteristic & ${\text { Sample }{ }^{\circ} \text { 1 }}^{\circ}$ & Sample ${ }^{\circ}{ }^{\circ}$ \\
\hline Depth [m] & 4.70 & 5.40 \\
\hline Water content nat ural [\%] & 7.08 & 6.38 \\
\hline Apparent densities (wet) [g/cm3] & 2.07 & 2.04 \\
\hline Content of organic matter [\%] & 0.84 & 0.31 \\
\hline Passing to sieves $80 \mu \mathrm{m}[\%]$ & 99.44 & 99.66 \\
\hline Content of clay (<2 $\mu \mathrm{m})[\%]$ & 59.24 & 56.76 \\
\hline Liquid limit [\%] & 65.20 & 81.87 \\
\hline Plastic limit [\%] & 30.01 & 34.23 \\
\hline Index of plasticity [\%] & 35.19 & 47.64 \\
\hline Activity of clay & 0.59 & 0.84 \\
\hline Water content optimum [\%] & 15.3 & 16.9 \\
\hline Density dries maximum [g/cm3] & 1.64 & 1.61 \\
\hline
\end{tabular}


Table 2. The data sheet of the Physical properties and chemical of lime Saida

\begin{tabular}{|c|c|}
\hline Basic characteristics & The dat a sheet of lime \\
\hline Physical appearance & White powder dries \\
\hline $\mathrm{CaO}[\%]$ & $>73.3$ \\
\hline $\mathrm{MgO}[\%]$ & $<0.5$ \\
\hline $\mathrm{Fe}_{2} \mathrm{O}_{3}[\%]$ & $<2$ \\
\hline $\mathrm{Al}_{2} \mathrm{O}_{3}[\%]$ & $<1.5$ \\
\hline $\mathrm{SiO}_{2}[\%]$ & $<2.5$ \\
\hline $\mathrm{SO}_{3}[\%]$ & $<0.5$ \\
\hline $\mathrm{Na}_{2} \mathrm{O}[\%]$ & $0.4-0.5$ \\
\hline $\mathrm{CO}_{2}[\%]$ & $<5$ \\
\hline $\mathrm{CaCO}_{3}[\%]$ & $<10$ \\
\hline Specific density [g/cm $]$ & 2 \\
\hline More than $90 \mu \mathrm{m}[\%]$ & $<10$ \\
\hline More than $630 \mu \mathrm{m}[\%]$ & 0 \\
\hline Insoluble material[\%] & $<1$ \\
\hline Apparent density [g/l] & $600-900$ \\
\hline
\end{tabular}

All the tests geotechnics were carried out according to standards AFNOR. Lime used is an extinct lime produced in the town of Hassasna, Unité Erco, wilaya of Saida, where the data sheet chemical and physical properties of the lime quoted by [3] is presented in (Table 2).

\subsection{Mineralogical and Che mical Analyses}

The diffractometer with $\mathrm{x}$-rays at summer used in this analysis in order to determine the different ones Proportions of minerals constituting the sample. On the diffractogram of the samples (Figure 1), the prevalent argillaceous mineral being the illite, the spectrum reveals also the presence of quartz, calcite, kaolinite and of montmorillonite, For the chemical analyses, the principal mineralogical components are: silica, alumina and the carbonates, the first two elements constitute the structure of clays.

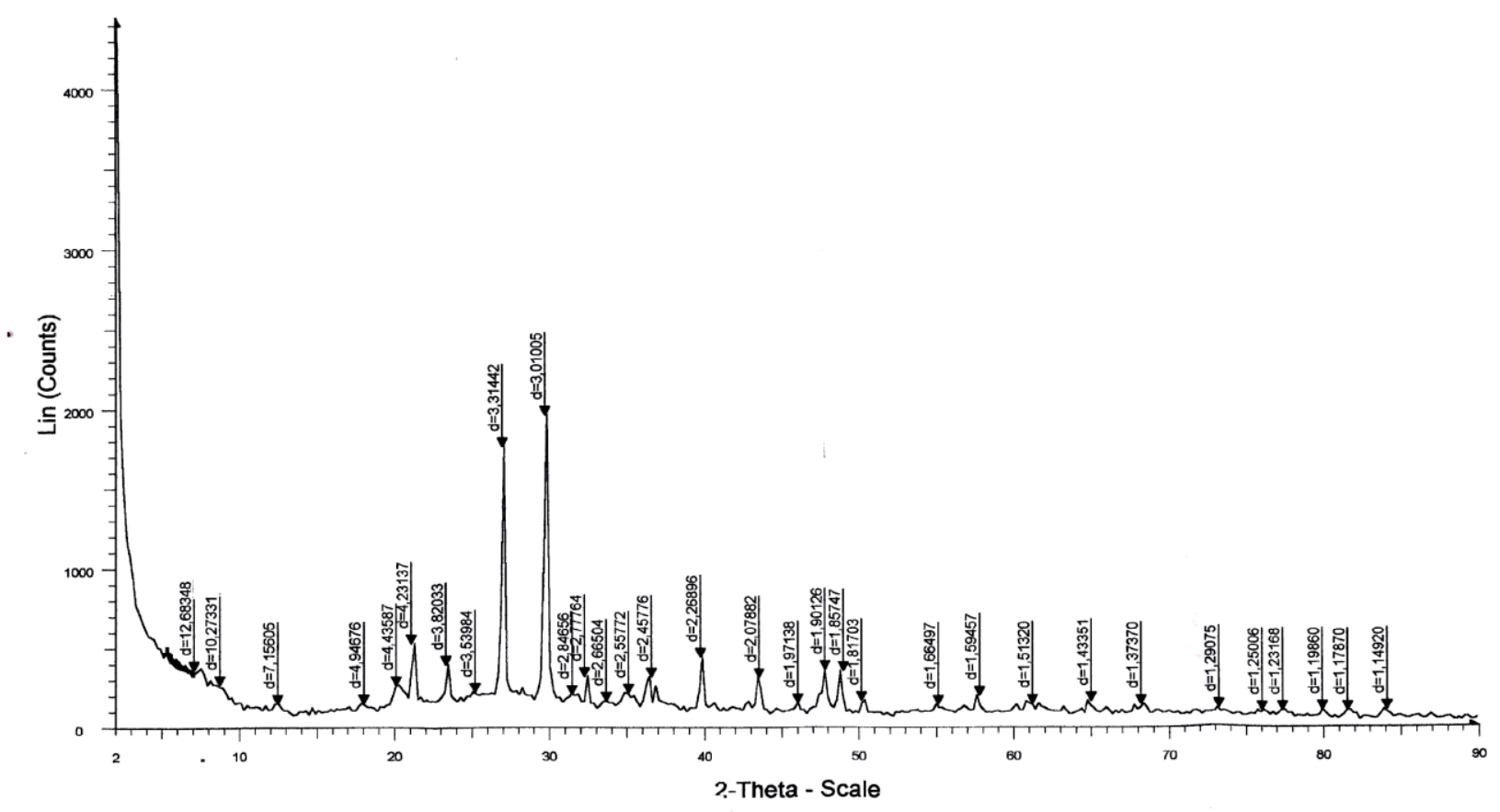

Figure 1. Diffract ogram X-ray of a marly clay sample of Ouled Fayet

\subsection{Electron Microscope with Sweeping}

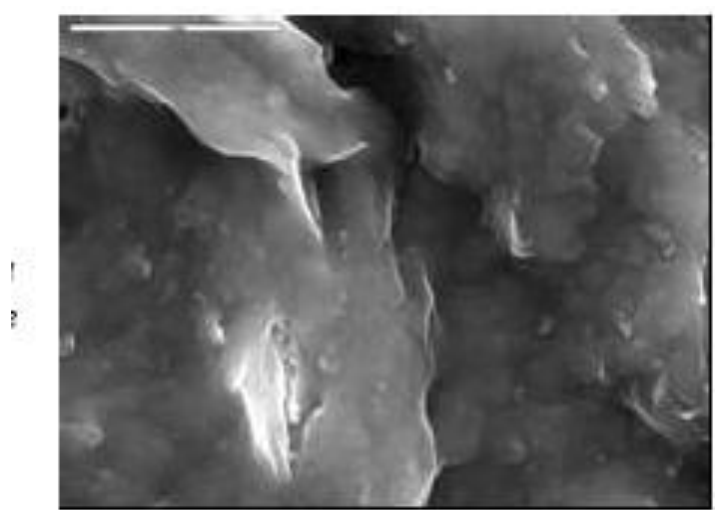

Figure 2. Electron microscope with sweeping of the marly clay of Cheraga - Ouled Fayet (Enlarging of X 7500)

The photography obtained by the electron microscope with sweeping was carried out on a fine powder of this type of marly clay of the area of the Sahel (Figure 2). Photography shows a white homogeneous surface and the presence of holes on surface indicating that our ground presents a certain porosity and an assembly of aggregates which is due to the presence of impurities.

\subsection{Classification Tests Physical}

According to the abacus of Standard, our grounds are classified among the clay soils very plastic, with an index of plasticity of $35.19 \%$ for 1 st and $47.64 \%$ for 2 nd. The activity corrected of [4,5] is given by the Formula (1) following:

$$
A \mathrm{c}=I p / c_{2}
$$

The value of blue, VB (test with the methylene blue) to deduce the value from total specific surface $(\mathrm{St})$ by the Formula (2) of [6] following:

$$
S s t\left[m^{2} / g\right]=21 V_{B}
$$


Table 3. The chemical composition of the two samples of ground +Saida lime Carried out at laboratory LC TP of Algiers

\begin{tabular}{|c|c|c|c|}
\hline \multirow{2}{*}{ Designation } & \multicolumn{3}{|c|}{ Chemical Composition [\%] } \\
\hline & Sample ${ }^{\circ} 1$ & Sample n $^{\circ} 2$ & Lime \\
\hline Silica $\mathrm{SiO}_{2}$ & 49.08 & 38.37 & 1 \\
\hline Alumina $\mathrm{Al}_{2} \mathrm{O}_{3}$ & 9.80 & 10.32 & 2.08 \\
\hline Ferrite $\mathrm{Fe}_{2} \mathrm{O}_{3}$ & 6 & 6.4 & \\
\hline Magnesia MgO & I & I & I \\
\hline $\mathrm{CaO}$ & 14.28 & 20.72 & 78.81 \\
\hline Sulphates(CaSO3, 2H2O) (Gypses) & Traces & Traces & Traces \\
\hline${\text { Chlorure } \mathrm{Cl}^{-}}^{-1}$ & 0.01 & 0.01 & $T$ \\
\hline Carbon dioxide (CO2) & 8.49 & 11.96 & 4.68 \\
\hline Carbonates $\mathrm{CaCO}_{3}$ & 19.3 & 27.19 & 7.88 \\
\hline Loss on the ignition with $1050^{\circ} \mathrm{C}$ & 17.93 & 20.3 & 35.76 \\
\hline Oxidize sodium $\mathrm{Na}_{2} \mathrm{O}$ & 0.29 & 0.22 & 0.29 \\
\hline Oxidize pot assium $\mathrm{K}_{2} \mathrm{O}$ & $\frac{1}{1}$ & $\frac{1}{1}$ & $\frac{1}{1}$ \\
\hline Organic matter & 0.84 & 0.31 & 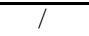 \\
\hline Boiler feed water $\left(\mathrm{H}_{2} \mathrm{O}\right)$ & 9.44 & 8.34 & 1.08 \\
\hline
\end{tabular}

One notices according to the values exposed in (Table 1 and Table 4) that the 2 samples are very plastic and extremely consistent material grounds, with a specific surface < to $180 \mathrm{~m}^{2} / \mathrm{g}$ thus it is containing illite and illitemontmorillonite according to classification LCPC-USCS with pressures of swelling high which remains to be confirmed by the indirect methods [7].

Table 4. Classification tests physics the soil

\begin{tabular}{|c|c|c|c|}
\hline parameters & Ac & $\mathrm{V}_{\mathrm{B}}$ & Sst \\
\hline Sample $^{\circ} 1$ & 0.594 & 6 & 126 \\
\hline Sample $^{\circ} 2$ & 0.84 & 6.5 & 137 \\
\hline
\end{tabular}

\subsection{Test Results of Compression Simple}

For a simple compression and to determine the resistance of compression and the corresponding deformation, one calls upon the triaxial apparatus with test unconsolidated not drained (UU) with a speed of crushing of $1 \mathrm{~mm} / \mathrm{min}$ and coefficient of ring 0.63 . The test consists in measuring the longitudinal deflection and the thrust load of the test-tube of ground made of cylindrical form with $5 \mathrm{~cm}$ of diameter and $10 \mathrm{~cm}$ height and with optimal characteristics which were obtained by the compaction Proctor preserved at the 28 jours and 45 days and treaties with lime $2 \%, 3 \%$ proportionings, $4 \%$ indicated in (Table $5)$.

Table 5. Influence conten ts lime on resistances of compression of the grounds

\begin{tabular}{|c|c|c|c|c|}
\hline $\begin{array}{c}\text { Samples } \\
\text { used }\end{array}$ & \multicolumn{2}{|c|}{${\text { Sample }{ }^{\circ} 1}^{\circ}$} & \multicolumn{2}{c|}{ Sample ${ }^{\circ} 2$} \\
\cline { 1 - 2 } Parameters & $\begin{array}{c}\text { Resistance } \\
\text { of } \\
\text { compression } \\
\text { to 28 days } \\
28 \text { days }\end{array}$ & $\begin{array}{c}\text { Resistance } \\
\text { of } \\
\text { compressio } \\
\text { n to } 45 \\
\text { days }\end{array}$ & $\begin{array}{c}\text { Resistance } \\
\text { of } \\
\text { pompressio } \\
\text { n to } 28 \\
\text { days }\end{array}$ & $\begin{array}{c}\text { Resistance } \\
\text { of } \\
\text { compressio } \\
\text { n to } 45 \\
\text { days }\end{array}$ \\
\hline $0 \%$ & 5.15 & 6.18 & 6 & 3.91 \\
\hline $2 \%$ & 5.84 & 5.64 & 7.82 & 4.82 \\
\hline $3 \%$ & 7.42 & 7.12 & 13.88 & 5.33 \\
\hline $4 \%$ & 7.35 & 13.56 & 15.41 & 6.77 \\
\hline
\end{tabular}

The contribution of lime with the clay soils to make them more resistant to compression since it is noticed that more than one increases the percentage of lime in the mixture (lime + clay) and the more a resistance a little larger is obtained, the clay soil thus becomes more compact and hardens more and more and what one also noted that one obtains a good resistance and increase very meaning by lime $4 \%$ for the two grounds (immediate resistance is unimportant even with the addition of lime), one can say that the resistance of compression to summer definitely improved with the addition from lime [6] and $4 \%$ is a sufficient content to improve the characteristics soil mechanics, which is in agreement with the literature. On building site for example this hardening makes the ground solid is easy to control and with the passage of the rollers of compaction (the compaction plant).
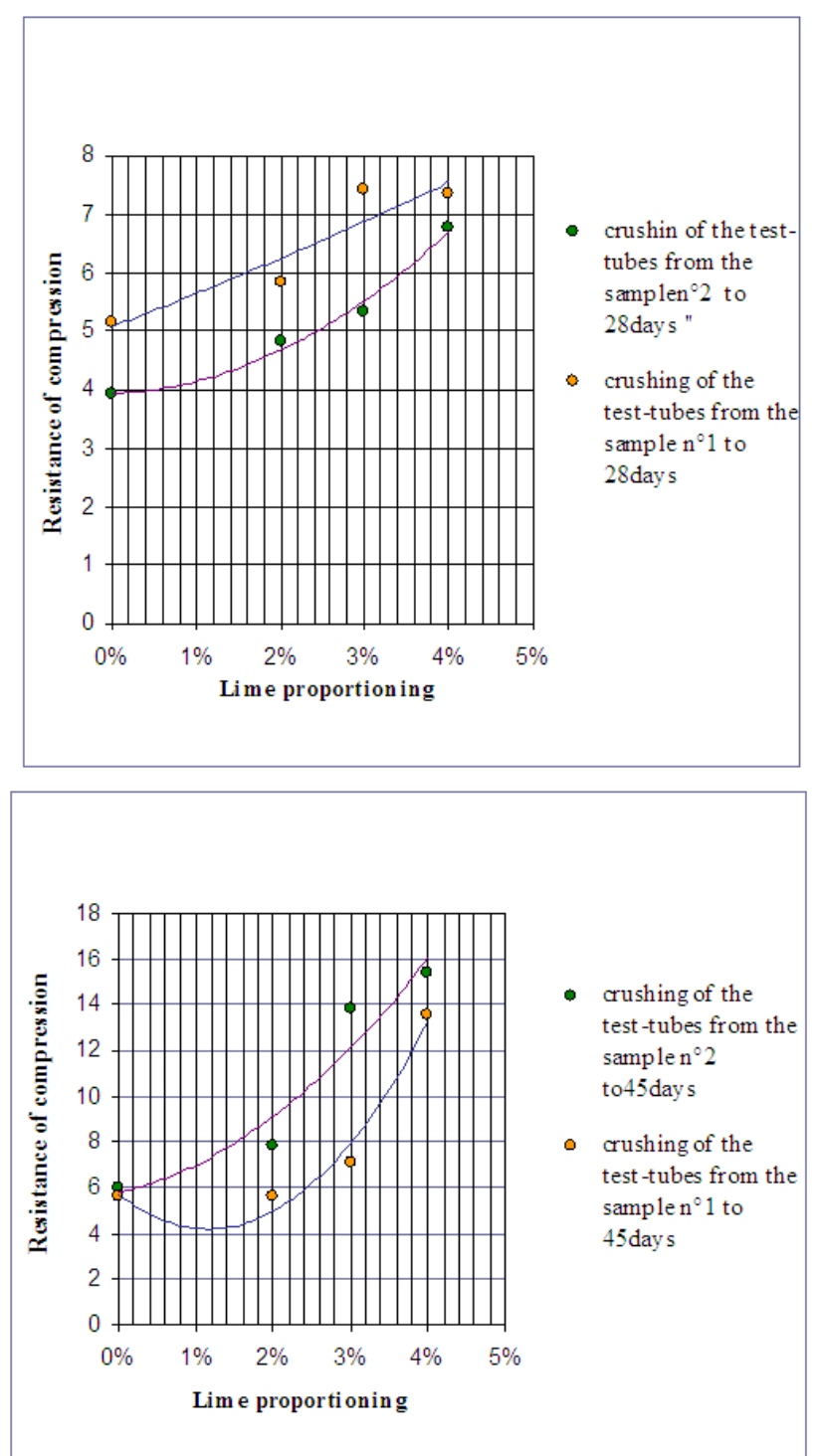

Figure 3. Influence cont ents lime on resistances of compression of the grounds to 28 days and 45 days 

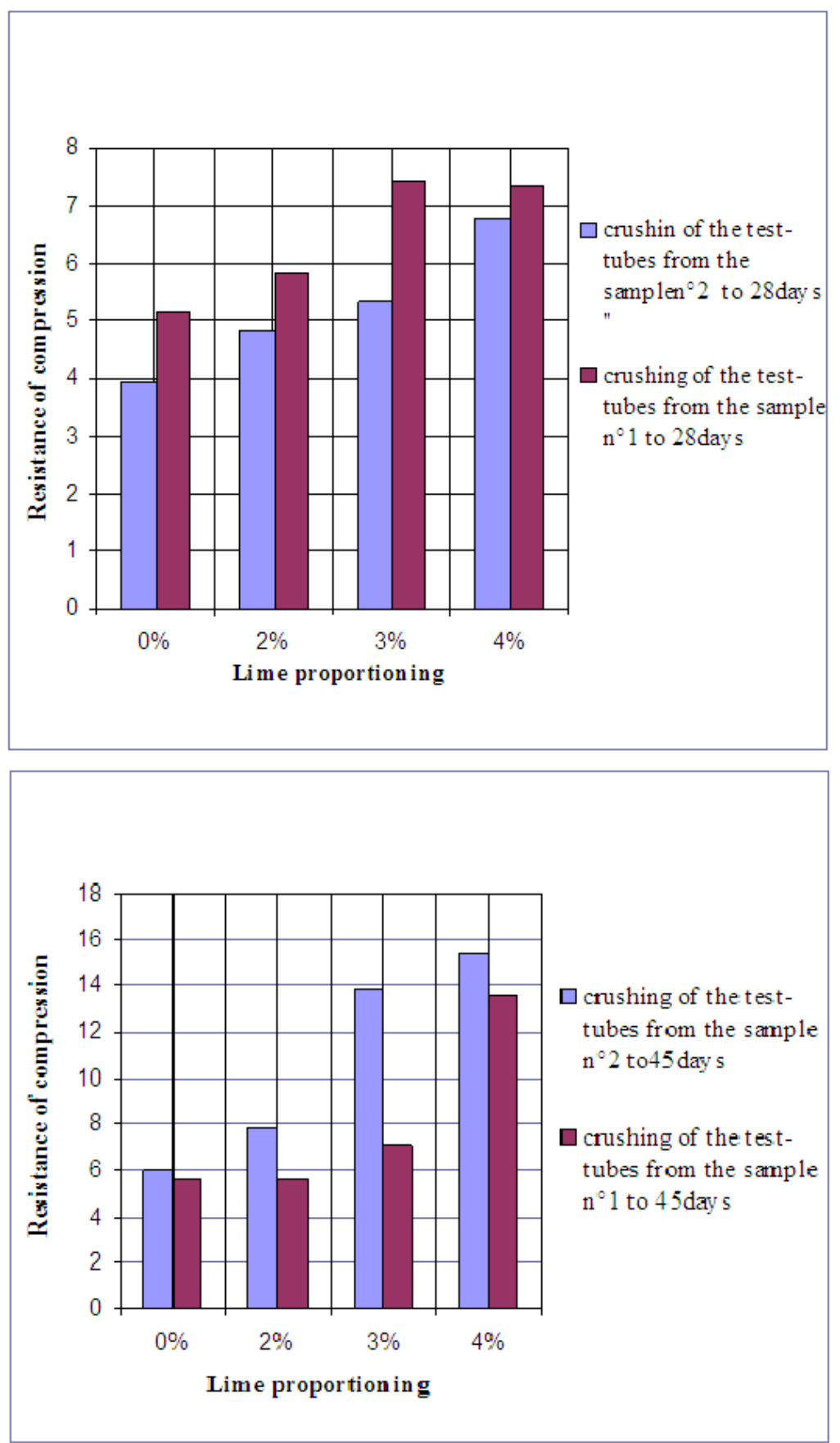

Figure 4. Hist ogram of resist ances of compression of the grounds according to lime proportionings to 28 days and 45 days

\subsection{Test Results of Shearing with Limps}

The two samples of ground are mixed with various lime proportionings $2 \%, 4 \%, 6 \%$ compacted statically and placed then in limp circular of $6 \mathrm{~cm}$ of diameter, the test adopted for shearing is "the consolidated test not drained", with a speed of shearing of $0.5 \mathrm{~mm} / \mathrm{min}$ the found results are registered in (Table 6).

\begin{tabular}{|c|c|c|c|c|c|c|c|c|c|c|}
\hline \multirow{3}{*}{$\begin{array}{c}\text { Samples used } \\
\text { Parameters } \\
\text { Lime } \\
\text { proportionning } \\
{[\%]}\end{array}$} & \multicolumn{5}{|c|}{ Sample $n^{\circ} 1$} & \multicolumn{5}{|c|}{ Sample $n^{\circ} 2$} \\
\hline & \multirow[b]{2}{*}{$C[$ bars $]$} & \multirow[b]{2}{*}{$\varphi\left[{ }^{\circ}\right]$} & \multicolumn{3}{|c|}{$\begin{array}{l}\tau \text { peak } \\
\text { [bars] }\end{array}$} & \multirow[b]{2}{*}{$C[$ bars $]$} & \multirow[b]{2}{*}{$\varphi\left[^{\circ}\right]$} & \multicolumn{3}{|c|}{$\tau$ peak } \\
\hline & & & $\sigma=1$ bar & $\sigma=2 \mathrm{bar}$ & $\sigma=3$ bar & & & $\sigma=1$ bar & $\sigma=2$ bar & $\begin{array}{c}\sigma \\
=3 \mathrm{bar}\end{array}$ \\
\hline 0 & 0.07 & 18.75 & 0.31 & 0.95 & 0.99 & 0.26 & 11.23 & 0.47 & 0.50 & 0.86 \\
\hline 2 & 0.08 & 21.45 & 0.95 & 0.68 & 1,25 & 0.15 & 17.23 & 0.47 & 0.79 & 1.65 \\
\hline 4 & 0.07 & 27.65 & 0.60 & 1.35 & 1,62 & 0.80 & 32.74 & 1.22 & 1.54 & 1.91 \\
\hline 6 & 0.67 & 23.90 & 0.99 & 1.56 & 1,99 & 0.32 & 25.18 & 0.22 & 1.26 & 1.73 \\
\hline
\end{tabular}



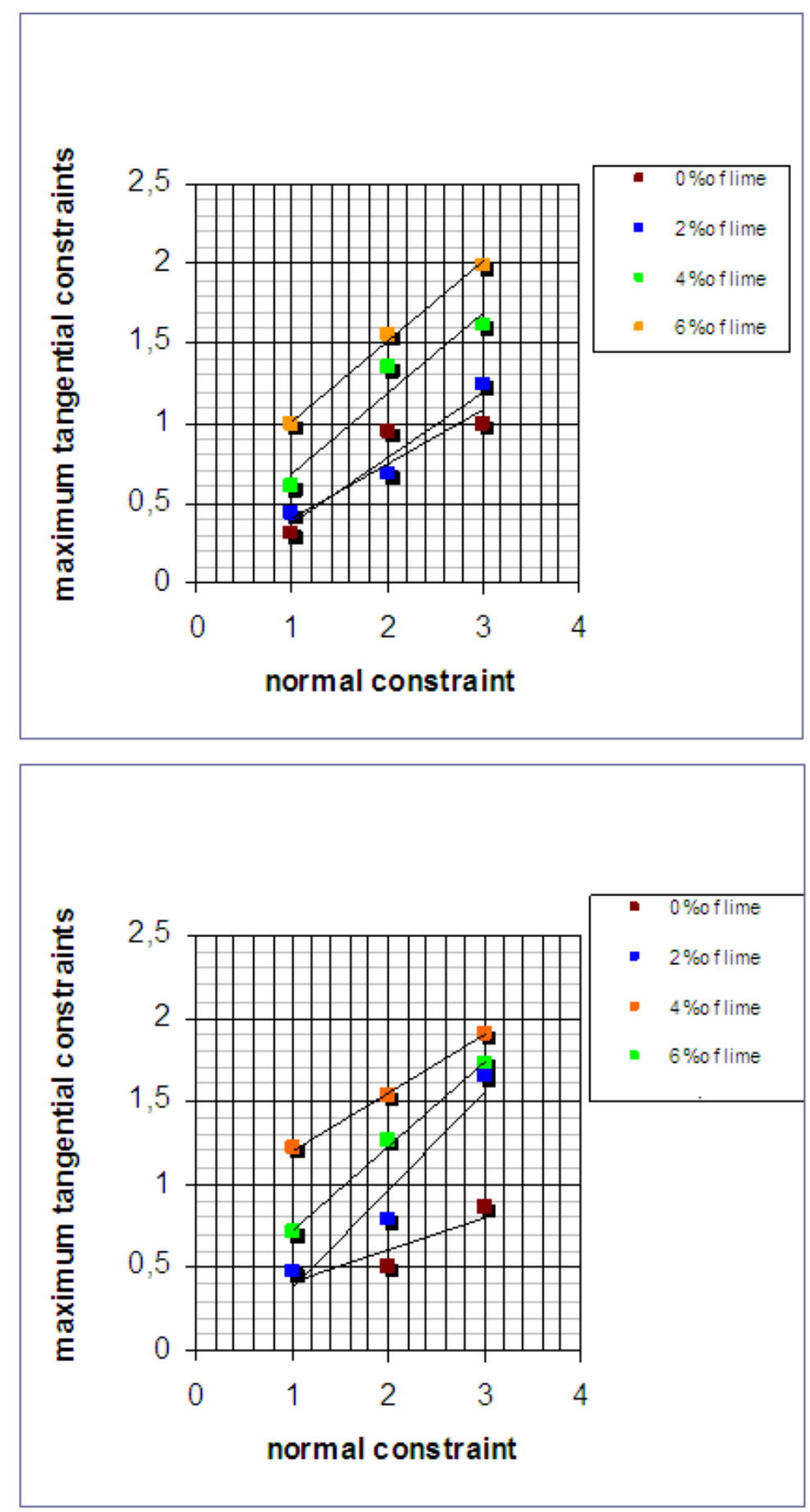

Figure 5. Curve of variation of resistances of shearing of the two samples according to lime proportioning

Lime also with increased the shear strength of the two clay soils into different proportionings and contents lime, the angle of friction for each lime proportioning knew the certain largest rise is to lime $4 \%$, then one notes a stabilization of this resistance from $6 \%$ thing for which it is said that lime improves mechanical qualities of clays, resistances are improved of way remarkable.

\section{Conclusion}

The incorporation of lime not only as decreases the inflating effect of the clay soils in this article one could conclude as:
- The addition of lime with double $4 \%$ compressive strength for the of Algiers clay soils it even content with given satisfactory results with respect to the shear strength which was improved and practically doubled with $4 \%$ of lime, the angle of friction knew increases in values the gold of various proportionings, the cohesion which was small initially knew a light improvement with $2 \%$ of proportioning for the sample $\mathrm{n}^{\circ} 2$ and a remarkable improvement with $4 \%$, the improvement of cohesion for the 1st sample was revealed to $6 \%$. This is with the reaction which takes seat when the ground is compacted is pozzolanic by nature. Quartz minerals, size of fine silt, in addition to minerals of clay, most probably take part in this reaction. Products with agglutinant reaction are formed and increased the capacity of resistance of the 
ground. principal agglutinant products are the calcium silicates and alu minates.
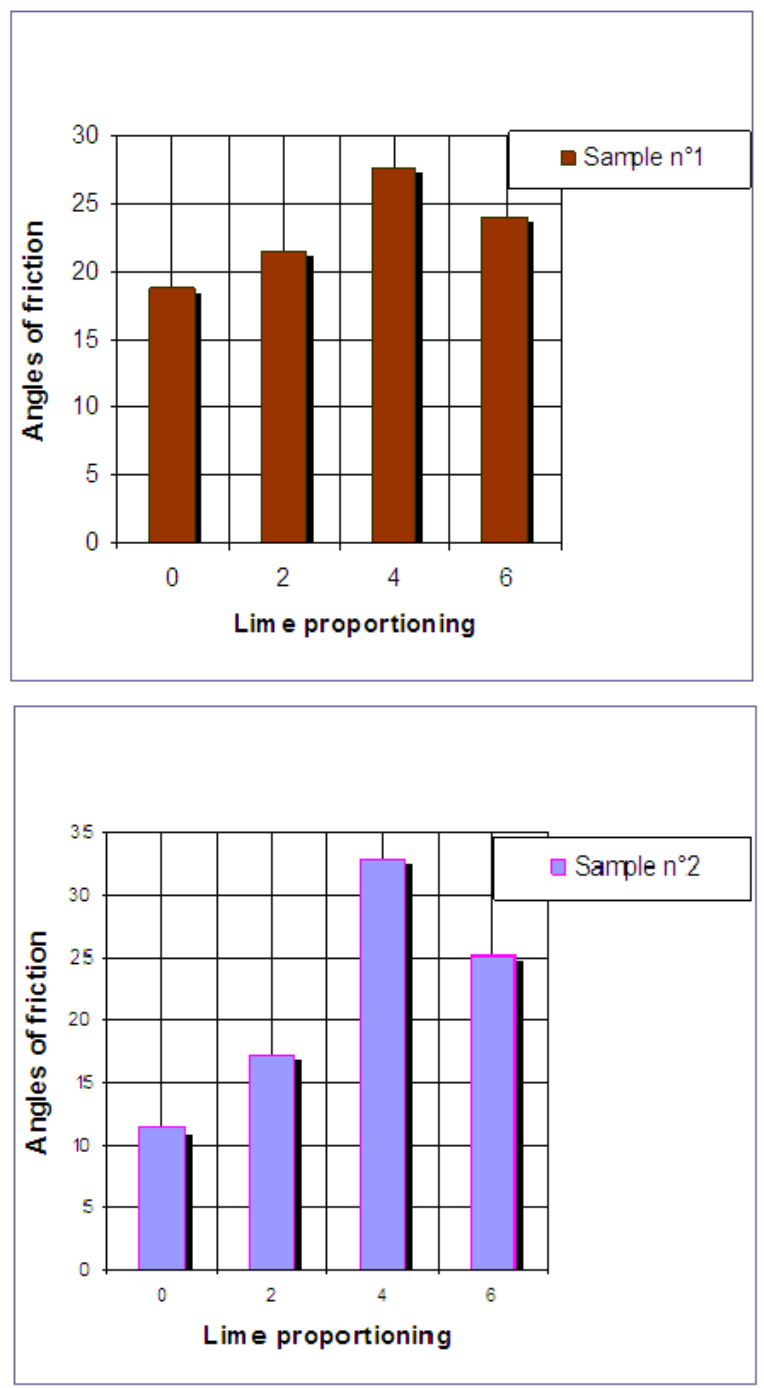

Figure 6. Hist ogram of variation of the angle of friction of the two samples according to lime proportioning

\section{Acknowledgement}

I would like to thank $\mathrm{Mr}$ Nechnech Ammar for his cooperation and his confidence in me, my gratitude goes to the mesieurs Aissa Mamoune, Bekkouche and Djeddid (professors at the University of Tlemcen in Algeria) who participated in the large part of the development of this topic and not forgetting Mr Bouafia (Professor at the University of Blida in Algeria) that got much encourage and me help writing this article.

\section{References}

[1] Bekkouche A., Djedid A. \& Aissa Mamoune S. M. 2002, "Identification and Forecast of the expansive ground heaving", symposium, Department of Civil engineering, FSI, University Aboubakr Belkaïd-T lemcen, Algeria.

[2] Gueddouda K.M., Smaida A., Mekerta B., Lamara M. \& Goual I. 2009, «Stabilization and shear strength of inflating clays [bentonite of Maghnia]", seminar international Department of Civil engineering, Institute of higher learning of the technological studies of Sfax, Tunisia.

[3] Azzouz F.Z. 2006, «Contribution to the study of the chemical stabilization of some inflating clays of the area of Tlem cen", thesis of magister, Department of Civil engineering, University of Tlemcen, Algeria.

[4] Seed H.B., Woodward R.J. \& Lundgren R., « Prediction of swelling potential for compacted clays», Journal of the soil Mechanics and foundations division. ASCE, vol 88, $\mathrm{N}^{\circ}$ SM4, 1962.pp.107-131.

[5] Harichéne K., Ghrici M., Belbbaci A. \& Meknaci A. 2009, "Effect of lime and natural pozzolana on the behavior of the plasticity of the clay soils", international Seminar, Department of Civil engineering, Institute of higher learning of the technological studies of Sfax, Tunisia.

[6] Ngoc Lan T., "Use of the test to the methylene blue in rad earthworks", Bulletin of connection of the Highways Departments, $\mathrm{N}^{\circ} 111,1981$, pp. 5-16.

[7] Ranganatham B.V. \& Satyanaryana B. 1965, « A rational method of preding swelling potential forcompacted expansive clays», Proc of the 6 th I.C.S.M.F.E. Montreal. 